\title{
Taxonomy and Ecology of the Lichens of the Ohaliksai River Basin
}

\author{
Masudjon Norkulov, Khislat Khaydarov, Zebiniso Umurzakova \\ Samarkand State University, Samarkand, Uzbekistan \\ Email: masud.norqulov@mail.ru
}

How to cite this paper: Norkulov, M., Khaydarov, K. and Umurzakova, Z. (2021) Taxonomy and Ecology of the Lichens of the Ohaliksai River Basin. American Journal of Plant Sciences, 12, 1380-1386. https://doi.org/10.4236/ajps.2021.129097

Received: August 5, 2021

Accepted: September 14, 2021

Published: September 17, 2021

Copyright (อ 2021 by author(s) and Scientific Research Publishing Inc. This work is licensed under the Creative Commons Attribution International License (CC BY 4.0).

http://creativecommons.org/licenses/by/4.0/ (c) (i) Open Access

\begin{abstract}
The article presents information about the taxonomy and ecology of lichens in the Ohaliksai River basin. According to the conducted studies, 11 families of the Lecanoromycetes class (Parmeliaceae, Lecanoraceae, Ramalinaceae, Megasporaceae, Physciaceae, Teloschistaceae, Peltigeraceae, Collemataceae, Candelariaceae, Umbilicariaceae, Physciaceae), 1 family of the Eurotiomycetes class (Verrucariaceae) and 1 family Lichinaceae of the class Lichinomycetes were identified, 18 groups and 23 species were noted as widespread. The taxonomic analysis and ecological characteristics of the identified species are presented.
\end{abstract}

\section{Keywords}

Lichen, Lichenomycota, Epilite, Epigee, Epiphyte, Epixyl, Epibriophyte, Tallom, Photobiont

\section{Introduction}

Lichen Division-Lichens, Lichenomycota occupies a special place among the lower plants. They are widely distributed on all continents of the Earth and are organisms adapted to grow in various environmental conditions, as well as in extremely unfavorable climatic zones. Lichens have the ability to grow at variable temperature and humidity, as well as on infertile soils. According to Tsurikov and Khramchenkova [1], lichens are one of the most widespread and at the same time the least studied organisms on the planet. According to the data, there are between 13,500 and 26,000 species of lichens in the world's flora. Lichens, complex algae, and fungi are complex symbiotic organisms that can survive in a variety of adverse environmental conditions.

Their metabolism is uniquely adapted to the adverse effects of the environ- 
ment, and they have developed a unique survival system. The secret to lichen's survival lies in its ability to withstand prolonged droughts. They grow in the mountains, at an altitude of $2400 \mathrm{~m}$ above sea level, even in Antarctica at temperatures up to $-60^{\circ} \mathrm{C}$. Lichens grow in a variety of environments, they are found in soil, tree bark, roots, rotten stumps, substrates with a high moisture content formed as a result of anthropogenic factors [2], and form specific associations. Lichens can grow with changes in temperature and humidity, on infertile soils, and even on rocks.

According to Kudratov [3], in Central Asia, 719 species of lichens, Bredkina, Makarova [4], etc., 219 species are distributed. According to other data, 325 species of lichens are distributed in Turkmenistan, 329 species in Kyrgyzstan, 132 species in Uzbekistan and 538 species in Tajikistan [3]. Accordingly, there is a lot of information on the systematic, taxonomy, and biogeography of the lichen flora common in Tajikistan, Kazakhstan, and Kyrgyzstan. However, scientific sources do not provide information about the flora, taxonomy, species composition and ecology of lichens in Uzbekistan.

This information is of great theoretical and practical importance. Therefore, we set ourselves the task of conducting lichenological studies in the middle reaches of the Zarafshan River.

\section{Materials and Methods}

During 2018-2021, the floristic composition and ecological characteristics of lichens in the Ohaliksai basin of the Koratepa mountain range, which is the northern part of the Zarafshan range, were studied (Figure 1).

Collection of lichens in nature and their identification, using the methods of Tsurikov, Khramchenkova [1], Muchnik, Insarova, Kazakova [5]. All studies and analyses were carried out in the laboratory of the Department of Botany of Samara State University. For macro- and micromorphological studies of herbarium materials, monocular microscopes M-15295, OPTICA MICROSCOPES, and

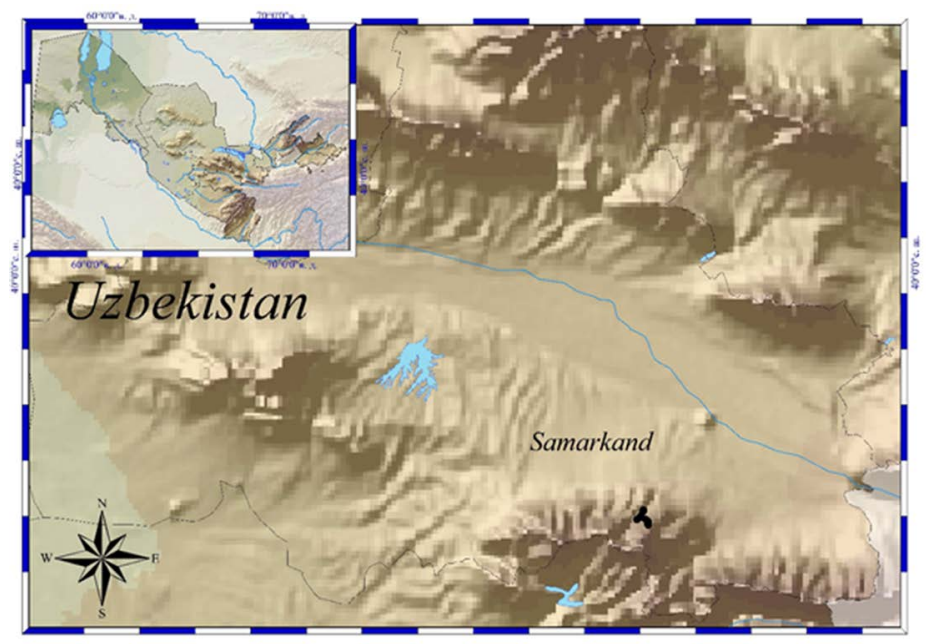

Figure 1. Map of Ohaliksai Basin Research Area. 
"Biolam" were used. The relevant scientific literature was used to determine the species composition of lichens and to study their morphological and classical features [1]-[11].

In the processing of systematic groups taxonomy of lichens, the databases were used waysofenlichenment.net, lichensmaritimes.org, lichenportal.org, gbif.org online Identification and "Cumulative Checklist for Lichen-forming, Lichenicolous, and Related Fungi of the Continental United States and Canada, version 22-23" (Castle 2018-2019) [7] [8].

During the study, more than 200 lichenological samples were collected from various environmental conditions. All samples are stored at the Department of Botany of Samarkand State University.

\section{Results and Discussion}

The Mountains of the Ohaliksai basin, due to their natural geographical location, are located in the northwestern part of the Koratepa mountain range and are part of the Zarafshan range system. The mountains of the Ohaliksai basin are located at an altitude of $1700 \mathrm{~m}$ above sea level.

According to the results of the study, 23 species of lichens grow in the Ohaliksai basin. They belong to 3 Classes (Lecanoromycetes, Eurotiomycetes, Lichinomycetes), 11 orders, 13 families, 18 groups (Table 1 ).

Table 1. Taxonomic analysis of lichens of the Ohaliksai

\begin{tabular}{|c|c|c|c|c|c|}
\hline Class & Orders & Families & Groups & $\begin{array}{l}\text { Number } \\
\text { of species }\end{array}$ & in $\%$ \\
\hline \multirow{14}{*}{ Lecanoromycetes } & \multirow{5}{*}{ Lecanorales } & \multirow{2}{*}{ Parmeliaceae } & Neofuscelia & 2 & $8.7 \%$ \\
\hline & & & Pleurosticta & 1 & $4.3 \%$ \\
\hline & & \multirow{2}{*}{ Lecanoraceae } & Lecanora & 2 & $8.7 \%$ \\
\hline & & & Rhizoplaca & 1 & $4.3 \%$ \\
\hline & & Ramalinaceae & Ramalina & 1 & $4.3 \%$ \\
\hline & Pertusariales & Megasporaceae & Aspicilia & 1 & $4.3 \%$ \\
\hline & Caliciales & Physciaceae & Physcia & 2 & $8.7 \%$ \\
\hline & \multirow{2}{*}{ Teloschistales } & \multirow{2}{*}{ Teloschistaceae } & Xanthoria & 1 & $4.3 \%$ \\
\hline & & & Caloplaca & 1 & $4.3 \%$ \\
\hline & Peltigerales & Peltigeraceae & Peltigera & 2 & $8.7 \%$ \\
\hline & Peltigerales & Collemataceae & Leptogium & 1 & $4.3 \%$ \\
\hline & Candelariales & Candelariaceae & Candelariella & 1 & $4.3 \%$ \\
\hline & Umbilicariales & Umbilicariaceae & Umbilicaria & 1 & $4.3 \%$ \\
\hline & Caliciales & Physciaceae & Phaeophyscia & 1 & $4.3 \%$ \\
\hline \multirow{2}{*}{ Eurotiomycetes } & \multirow{2}{*}{ Verrucariales } & \multirow{2}{*}{ Verrucariaceae } & Dermatocarpon & 2 & $8.7 \%$ \\
\hline & & & Placidium & 1 & $4.3 \%$ \\
\hline Lichinomycetes & Lichinales & Lichinaceae & Lichinella & 3 & $13 \%$ \\
\hline 3 & 11 & 13 & 18 & 23 & 100 \\
\hline
\end{tabular}


The studied lichens can grow in soil, trees, rocks, and other conditions. Lichens were divided into several ecological groups depending on their relationship to the environment and external factors: epigee, epilyte, epiphyte, epixyl, epibriophyte and epiphyll lichens. We collected herbarium samples and divided according to samples by species composition ( 23 species), ecological groups and families (Table 2).

According to the table, the identified lichens belonged to 10 types of epithelites, depending on their relationship to the substrates. They accounted for $44 \%$ of the total number of species. In addition, the various species include 5 epigeia, 4 epiphytes, 1 epixylae, and 3 epibriophytes.

Epigee lichens grow in soils (sandy, peat, gravel). These include such species as, Physcia tribacia (Ach.) Nyl., Caloplaca tomini (Savicz) Ahlner., Peltigera canina (L.) Willd., Peltigera rufescens (Weiss) Humb., Candelariella spraguei (Tuck.) Zahlbr., Placidium squamulosum (Achlbr.) Brace.

Epileptic lichens develop in a rocky environment. These include species belonging to the family Parmeliaceae, Lecanoraceae, Megasporaceae, Physciaceae, Teloschistaceae, Collemataceae, Candelariaceae, Umbilicariaceae, Verrucariaceae, and Lichinaceae. Of these species in the family, such species as Xanthoria elegans (Link) Th. Fr., Dermatocarpon minimatum (L.) W. Mann., Lichinella nigritella (Lettau) P. P. Moreno et Egea are widely distributed (Figure 2).

Epiphytic lichens grow on the bark, stems, and branches of trees and shrubs

Table 2. Ecological groups of lichens depending on their growing environment.

\begin{tabular}{cccccc}
\hline Families & Epigee & Epilyte & Epiphyte & Epixil & Epibriophyte Epiphyll \\
\hline Lecanoromycetes & & & & & \\
Parmeliaceae & & + & + & & \\
Lecanoraceae & & + & & & \\
Ramalinaceae & & & + & & \\
Megasporaceae & & + & & & \\
Physciaceae & + & + & + & & \\
Teloschistaceae & + & + & & & + \\
Peltigeraceae & + & & & + & + \\
Collemataceae & & + & + & & + \\
Candelariaceae & + & + & & & \\
Umbilicariaceae & & + & & \\
Physciaceae & & & & \\
Eurotiomycetes & & & & \\
Verrucariaceae & + & + & & \\
Lichinomycetes & & & & \\
Lichinaceae & & & & \\
& & &
\end{tabular}


and include Scum, or crusty, Bushy, leafy forms. They use the substrate only as a habitat. Among the identified species are Pleurosticta aceabulum (Neck.) Elix et Lumbsch., Ramalina pollinaria (Westr.) Ach., Physcia biziana (A. Massal.) Zahlbr., P. tribacia (Ach.) Nyl., Leptogium asiaticum P. M. Jorg. they belong to such types.

Epicyl lichens-develop in treated wood, rotten wood, and rotten trunks of deciduous and shrub species. According to the research, this group includes the species Peltigera canina, $P$. rufescens, belonging to the family Peltigeraceae.

Epibriophytic lichens grow on turf with moss (forests in the northern region, in very humid environments). These include the species Caloplaca tomini (Savicz) Ahlner., Peltigera canina, P. rufescens, Leptogium asiaticum, Placidium squamulosum (Ach.) Breuss. (Figure 3).

Epiphyll lichens always grow on the leaves and needles of coniferous trees, their number is usually small, common in tropical and subtropical regions, so
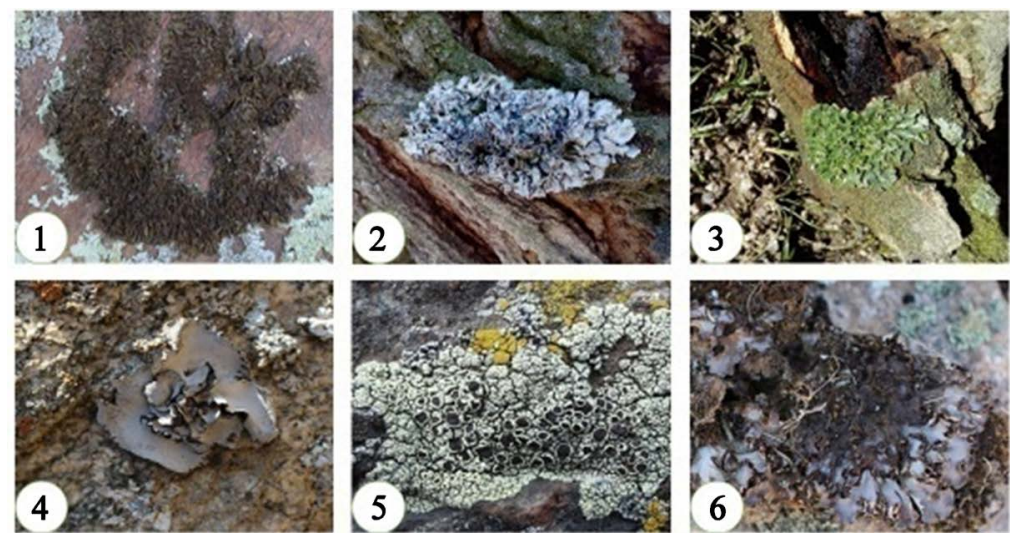

Figure 2. General view of focal species. Comment: 1. Neofuscelia pulla; 2. Physcia biziana; 3. Pleurosticta acetabulum; 4. Dermatocarpon miniatum; 5. Lecanora argopholis, 6. Peltigera canina).

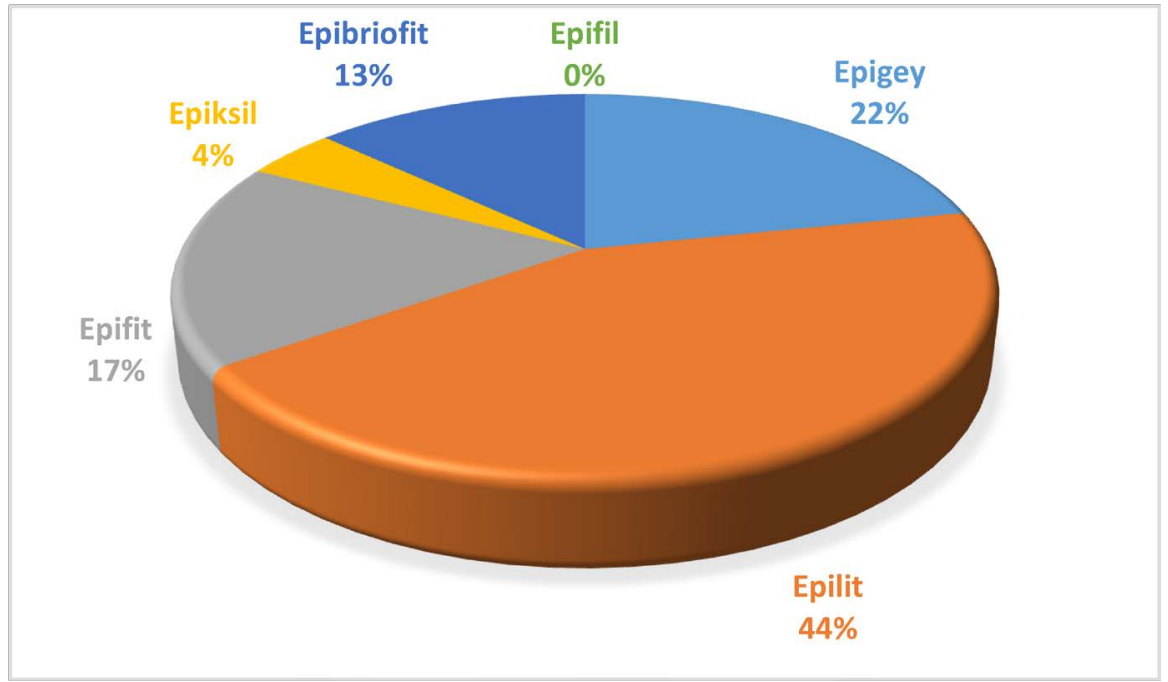

Figure 3. Ecological groups of lichens depending on their relation to the environment and external factors. 
they are not found in the territory we studied.

The species analysis of lichen moisture in the study area revealed 6 species of mesohygrophytes (26.09\%), 8 species of mesophytes (34.78\%), 6 species of xeromesophytes (26.09\%), and 3 species of xerophytes (13.04\%) (Table 3).

Mesophytic lichens can be found in the Ohaliksai basin during periods of high humidity (early spring, late autumn and partial winter), mainly on rocks, sand and gravel on the banks of ravines and in the bark of trees where sunlight does not reach. With a significant decrease in humidity, they pass into a period of rest. This ecological group includes Peltigera canina, P. rufescens, and others.

It is noted that xerophytic lichens grow in spring, summer and autumn on the southern and south-western slopes of the mountains, on large stones under constant sunlight, in the bark of trees and on the surface of dry soils. We identified from xerophytic lichens on these media Xanthoria elegans (Link) Th. Fr. and Lecanora muralis (Schreb.) Rabenh. These species are common on rocks, trees and shrubs in the southern and southwestern parts of the mountains, as well as on the surface of the soil.

Xeromesophytic lichens are known to develop in spring and autumn. In summer, they were found only in wet places where there is no direct sunlight. The most common of these are Placidium squamulosum and Dermatocarpon minimatum.

Lichinella nigritella lichen grows in shallow gravelly and flooded areas in the upper part of the Ohaliksaya region. This species is a mesohygrophyte. Hydrophytic lichens are very specific aquatic lichens that spend constantly or most of the year underwater. These lichens have not been studied biologically, and hydrophytic lichens have not been identified in our studies. Among the aquatic and terrestrial species in the habitat, there are a number of similar species. These species can withstand floods for a long time, but there are also species that usually live out of the water. These are Rhizocarpon obscuratum (Ach.) A. Massal. (Rhizocarpon reductum Th. Fr.), Lecidea albocoerulescens (Wulfen.) Hertel \& Knoph. and other types.

\section{Conclusions}

1) According to the research, 23 species of lichens were identified in the Table 3. Analysis of the ratio of lichens to humidity.

\begin{tabular}{cccc}
\hline № & Ecological groups & Number of species & In \% ratio \\
\hline 1 & Hydrophytes & - & 0 \\
2 & Mesohydrophytes & 6 & $26.09 \%$ \\
3 & Mesophytes & 8 & $34.78 \%$ \\
4 & Xeromesophytes & 6 & $26.09 \%$ \\
5 & Xerophytes & 3 & $13.04 \%$ \\
& Total: & 23 & $100 \%$ \\
\hline
\end{tabular}


Ohaliksai basin. These are species belonging to 3 classes (Lecanoromycetes, Eurotiomycetes, Lichinomycetes), 11 orders, 13 families, and 18 genera.

2) 10 of the identified lichen species ability (44\%), 5 species ability (22\%), 4 epiphytes (17\%), type 1 epixel (4\%) and type 3 epibiotic (13\%).

3) Humidity lichens in the study area the mesohygrophytes were 6 types $(26.09 \%)$, mesophytae 8 kinds (of 34.78\%), xeromesophyte 6 types (26.09\%), species 3 species (13.04\%).

\section{Conflicts of Interest}

The authors declare no conflicts of interest regarding the publication of this paper.

\section{References}

[1] Tsurikov, A.G. and Khramchenkova, O.M. (2009) Leafy and Bushy Urban Lichens: Atlas-Determinant: A Textbook for Students of Biological Specialties of Universities. Gomel State University, Skoriny, 123-125.

[2] Ismailov, A.B. and Asadulaev, Z.M. (2016) Atlas of Lichens of Dagestan//Makhachkala. DSU Publishing House, Makhachkala, 199 p.

[3] Kudratov, I. (2004) Analysis of the Lichenoflora of Tajikistan. N. G. Kholodny Institute of Botany of the National Academy of Sciences of Ukraine-Kiev, 22 p.

[4] Bredkina, L.I. and Makarova, I.I. (2005) Annotated List of Lichens of the Central Tien Shan (Kyrgyzstan)//News of the Taxonomy of Lower Plants (Volume 39). Institutum of Botany name of after Komarovii, St. Petersburg, 199-218.

[5] Muchnik, E.E., Insarova, I.D. and Kazakova, M.V. (2011) Educational Determinant of Lichens of Central Russia: Educational and Methodological Manual. Ryazan State University named after S. A. Yesenin, Ryazan, 360 p.

[6] Tsurikov, A.G. and Korchikov, E.S. (2018) Determinant of Lichens of the Samara Region. Part 1. Leafy, Bushy and Slimy Species: Samara. Samara University Publishing House, Samara.

[7] Esslinger, T.L. (2019) A Cumulative Checklist for the Lichen-Forming, Lichenicolous and Allied Fungi of the Continental United States and Canada, Version 23. Opuscula Philolichenum, 18, 102-378. http://sweetgum.nybg.org/philolichenum/

[8] Esslinger, T.L. (2018) A Cumulative Checklist for the Lichen-Forming, Lichenicolous and Allied Fungi of the Continental United States and Canada, Version 22. Opuscula Philolichenum, 17, 6-268. http://sweetgum.nybg.org/philolichenum/.

[9] Matwiejuk, A. (2012) Rhizocarpon lavatum and $R$. reductum (Rhizocarpaceae, Ascomycota), Two Misunderstood Taxa Found in the Gorce Mts (Polish Carpathians). Acta Mycologica, 47, 121-126. https://doi.org/10.5586/am.2012.013

[10] Thell, A., Crespo, A., Divakar, P.K., Kärnefelt, I., Leavitt, S.D., Thorsten Lumbsch, H. and Seaward, M.R.D. (2012) A Review of the Lichen Family Parmeliaceae-History, Phylogeny and Current Taxonomy. Nordic Journal of Botany, 30, 641-664. https://doi.org/10.1111/j.1756-1051.2012.00008.x

[11] Wei, X.L., Wang, X.Y., Koh, Y.J. and Hur, J.-S. (2009) Taxonomic Study of Peltigera (Peltigeraceae, Ascomycota) in Korea. Mycobiology, 37, 189-196.

https://doi.org/10.4489/MYCO.2009.37.3.189 